\title{
Regulation of Bank Trust Department
} Investment Activities*

\author{
Martin E. Lybecker ${ }^{\dagger}$
}

\section{Introduction}

Among the most powerful (and most anonymous) of our nation's financial institutions are bank trust departments. They manage assets substantially exceeding the assets of the largest one hundred corporations in the United States. ${ }^{x}$ In fact, bank trust departments have larger securities portfolios than all other institutional investors combined.? As a result, certain commercial banks have the potential power to control major corporations. ${ }^{3}$

Yet, the regulation of bank trust departments seems cursory in many respects compared to that applied to other institutional investors. Only superficial data are gathered by bank examiners, whose responsibilities relate primarily to the banks' other departments. Even less information is made available to the public. In the past, recommendations for reform have focused on increasing public disclosure of investment activity ${ }^{4}$ and making trust department regulation similar to that of other financial institutions. ${ }^{5}$

* After substantial completion of this Article, the author became a member of the staff, Division of Investment Management Regulation, Securities and Exchange Commission. The Securities and Exchange Commission, as a matter of policy, disclaims responsibility for any private publication by its emplojees. The views expressed hercin are those of the author and do not necessarily reflect the views of the Commission or any of its staff. The author wishes to thank for their invaluable assistance Professor Robert H. Mundheim and Mr. Reese H. Harris, Jr., Director and Advisory Council Mem. ber, respectively, of the University of Pennsylvania Law School Center for the Study of Financial Institutions.

$\dagger$ B.B.A. 1967, University of Washington, J.D. 1970; LL.M. (in Taxation) 1971, New York University; Candidate for LL.M. degree, Spring 1973, University of Pennsylvania. Nember, Washington State and District of Columbia Bars.

1. As of 1971, the total assets managed by bank trust departments were valued at 336 billion dollars. Patman, Other People's Afoney, TuE New Repunuc, Feb. 17, 1973, at 14. Based on 1971 figures, the largest one hundred corporations had less than 300 billion dollars worth of assets. See Fortune Double 500 Directory (1972).

2. The amount of all bank trust departments' securities holdings exceeded the sum of securities administered by investment advisors, insurance companies, self-administered employee benefit plans, foundations, and education endowments. SEC, INSTrumoNAL INvestor STUdY REPORT, H.R. Doc. No. 64, 92d Cong., Ist Sess. pt. 2, at 413.14 [hereinafter cited as IIS REPORT]. As of April, 1968, the size of bank trust departments securities holdings was \$238.6 billion. STAFF REPORT FOR THE HOUSE SUBCoMrs. ON DOMESTIC FINance, Comm. on Banking and Currency, 90ti CoNg., 2b Sess, Commerciat Basks AND Their TRUST Actrvities: EMIERGING INFLUENCE ON THE AMERICAN ECONOMY 47 (Comm. Print 1968) [hereinafter cited as PATMan REPORT].

3. Patman Report, supra note 2.

4. The SEC has recommended that all professional portfolio managers, including those not presently registered with the SEC, provide improved public disclosure of investment return, portfolio volatility, and short-term trading. IIS REPORT, supra note 2, pt. 1, at XI, XIII.

5. Report of the President's Commission on Financial Stmucture and Rraumation (1971) [hereinafter cited as Hunt Commission Report]. The Hunl Commission Report recommended that the bank examining agencies assure themselves that banks were not 
This article concentrates instead on the bank examination processand suggests that it be upgraded to preclude practices exploiting loopholes in the present laws. It also proposes that the Securities and Exchange Commission be given jurisdiction to collect information about bank securities and portfolio management policies.

\section{Bank Trust Department Investment Practices and Regulatory Responses ${ }^{6}$}

The overriding reason for examining commercial banks ${ }^{7}$ generally has been to assure bank depositors of the bank's continuing solvency. ${ }^{8}$ Bank trust department examinations are conducted by regulatory agencies $^{9}$ and bank directors ${ }^{10}$ to assure that the trust department has

trading on the basis of commercial department or other "inside" information, werc properly investing cash, and were properly handling the commission brokcrage of their securities transactions.

6. To obtain some insight into bank trust department examinations and investment activities, confidential interviews were conducted with regulatory agency officials and bank trust department officers during the first four months of 1972 . Officials of several states and several branches of all three federal regulatory agencies were intervicwed. Also interviewed were officers of several banks in each major Eastern moncy-center city, in several major Midwest money-center cities, and in several major Southern money-center cities. A prerequisite to obtaining interviews with federal regtilatory agency officials and bank trust department officers was the author's agreement that the sources of infor. mation would not be identified.

7. Definitions of certain terms used in this Article may be helpful to the rcader. $\Lambda$ "commercial bank" for purposes of this Article means a corporation that engages in receiving demand deposits subject to checks and "time and savings" deposits. Using thesc deposits, the corporation makes loans of various kinds, including business, consumer, personal and real estate loans. The term "bank" or "bank complex" is used here to mean a commercial bank which may provide trust services to its customers, and not a mutual savings bank, savings and loan association, insurance company, finance company or other financial institution which may compete with banks but docs not meet the traditional concept of a commercial bank. A "trust company" is a state-chartered corporation empowered by its charter to engage in all kinds of trust activities; it may or may not be a commercial bank. Generally, trust companies are not subject to federal regulation; and thus, they are outside the scope of this Article.

8. See, e.g., Davis, Banking Regulation Today: A Banker's View, 31 LAw \& Conten'. Prob. 639, 640 (1966); Masters, Trust Examinations-Development of Supervisory Protec. tion for Better Service, 93 Trust \& Estates 280, 282 (1954). But see Miller, Trust Supervisor's Role-Improved Services Through Exchange of Ideas Between Trustmen and Su. pervisory Authority, 103 TRUst \&: Estates 1244 (1964).

9. All national banks are examined by the Comptroller of the Currency; certain state. chartered member banks of the Federal Reserve System are examined by the regional Federal Reserve bank; and all remaining state-chartered, non-Federal Reserve system binks insured by the FDIC are examined by the FDIC. See IIS REPORT, supra note 2, pt. 2, at 442. 43; Robertson, Federal Regulation of Banking: A Plea for Unification, 31 LAw \& CoNreM1. Prob. 673, 674 (1966) [hereinafter cited as RoBERTson]. Non-insured banks and trust companies are regulated only by whatever local state regulatory agency has jurisdiction over the respective financial institution. Only the Federal Reserve presently has trust examination specialists; the FDIC and Comptroller examiners are basically commercial bank examiners who have some degree of familiarity with trust examinations. See ren. erally C. Golembe, The Economic Power of Commercisl BANKs 56.59 (1969); Randall, The Federal Deposit Insurance Corporation: Regulatory Functions Philosophy, 31 LAw \& Contemp. Prob. 696 (1966). Few state banks administering trust assets operatc outside the FDIC insurance umbrella of $\$ 20,000$ per deposit; at the end of 1969 , there were 3,289 insured banks and only forty-nine non-deposit, non-insured trust companies. FDIC ANN REP. 242 (1969). Thus, very few bank shareholders were without the benefit of some federal oversight.

10. State and federal laws require that directors of banks conduct annually their own 
not breached its fiduciary duties and subjected the bank to potential suits which might threaten its solvency. ${ }^{11}$ Rather than prohibit absolutely by rule specific activities, bank regulatory agencies have long informally prescribed what sound fiduciary principles require. ${ }^{12}$ This traditional informality may be maintained by expanding the role of the individual trust examiner. As an improved trust examination process would provide a natural occasion for communication between the regulators and the regulated, it may ultimately strengthen bank self-regulation. The reforms envisioned by this section can be adopted by mutual consent of examiners and banks, or if necessary by rulemaking within existing bank regulatory agencies.

\section{A. Conforming Investments}

Bank trust investment activity must conform with the explicit investment directions of a trust instrument ${ }^{13}$ and with general fiduciary principles. Trust accounts with specific investment restrictions are reviewed yearly for conformity to the instrument's express limitations; the unrestricted trust instruments, those giving the trust department unlimited investment discretion, are reviewed broadly for conformity to "prudence,"14 through a perusal of both a trust department's "approved list"15 and its actual holdings. The present system has two possible defects. First, the trust examiners may be able to review only a third or a quarter of the large number of restricted trust accounts each year. ${ }^{16}$ Second, the test for "prudence" has been unsophisticated: it has meant scrutiny only of the risk profiles of individual securities,

internal examination. See, e.g., CAL. Fin. Cone ANw. \$ 1902 (West 1968, Supp. 1971); N.Y. Banking Law \$ 122 (McKinney 1971); 7 PA. AxN. STAт. \$ 1407(a) (Purdons 1968). See, e.g., 12 C.F.R. $\$ 9.9$ (1972). Because this section of the Comptroller of the Currency's Regulations is usually referred to as Regulation 9 by persons in the banking industry, it will hereinafter occasionally be referred to as such.

11. E. NeIlan, Trust Examination: AN Examiner's ANalysts 28 (1939) [heteinaftcr cited as NEILAN].

12. Miller, Regulation of Fiduciaries, Amer. Bankers Ass'N, Procendinas, Fiduchari RESPONSIBILITY SEMINAR 56, 58 (July 22, 1970) [hercinafter cited as MIILLER].

13. NeILAN, supra note 11, at 54-57; 12 C.F.R. $\$ 9.11$ (1972).

14. An "approved list" generally consists of several hundred securities which hase received the trust department investment committee's approval for investment by trust accounts.

15. State law, statutory and judicial, may be applicable to the investunent powers of a trustee when the trust instrument is silent or simply follows state law. Thus, the "prudent man" rule, since it is rarely waived in the trust instrument, is usually the ultimate test. See, e.g., Harvard College v. Amory, 26 Mass. (9 Pick) 446, 461 (1830). For a discussion of present fiduciary investment practices and policy, sce Trustec's Duties Regarding Investments, 4 Real Prop., Prob. \& TruST L.J. 604 (1969). Liability is now incurred when the trustee violates his duty "to make such investments as a prudent man would make of his own property having primarily in view the prescriation of the estate and the amount and regularity of income to be derived." $2 \mathrm{~A}$. Scotr, LAW of Tnusts 1409-10 (3d ed. 1967) [hereinafter cited as Scort].

16. Comptroller of the Currency, Comptroller's Mianual for Represestatives in TRUST 46, 60 (1969) [hereinafter cited as CoMptroliER's MrANUAL]. 
when wise investment or portfolio practice may demand a mix of speculative and blue-chip securities.

Trust examiners and bank trust department officials agree that the incidence of non-conformity is very small in relation to the number of trust accounts under management. ${ }^{17}$ In part, this low incidence may be attributable to the periodic review for clerical errors and nonconformance performed by account managers, trust departments' investment committees, and the banks' internal auditors. Also, since trust departments are generally required by state law to review each trust account at least annually, ${ }^{18}$ trust examiners may review for conformity in effect when they review a trust department investment committee's minutes.

As to the meaning of "prudence," a more useful test than the performance of individual securities may be the risk profile and total return of the entire investment portfolio. ${ }^{10}$ Based on portfolio theory, ${ }^{20}$ the total return concept posits that reasonable investment decisions can be made on the basis of risk ${ }^{21}$ and expected return. Use of the total return concept enables the investor to balance the riskiness of his investment portfolio against his outside investments in risk-free assets, such as U.S. Savings Bonds. ${ }^{22}$ Because these investments are risk-frec, his investment portfolio can accept greater risks and produce a larger total return. Also, diversity in terms of the number and speculativeness of individual securities is necessary because the general risk of an investment portfolio is not the weighted average of the risks of the individual securities. ${ }^{23}$ Rather, to the extent that prices of individual securi-

17. An average figure for nonconformity, corroborated by bank regulatory agencics and trust department officials, is four or five accounts per thousand trust accounts under management.

18. Neilai, supra note 11, at 56. See Comptroller's Manual, supra note 16 , at 64.

19. Briefly, this concept focuses on the total return generated by the investment portfolio over a period of time, rather than on specific gains or losses on the individual securities in the portfolio. A parallel to the trust examiner's review for conformity has long existed in the securities law concept of suitability. Some commentators have recommended the total return concept as a useful test for suitability or conformity. Note, The Regulation of Risky Investments, 83 HARv. L. REv. 603, 617 (1970) [hereinafter cited as Harvard Note]. See also Cohen, The Suitability Rule and Economic Theory, 80 YALE L.J. 1604, 1609 (1971) [hereinafter cited as ConEN]. Under the suitability doc. trine, a broker must determine before making any investment recommendations what financial circumstances (e.g., restrictions) each customer enjoys, just as a trust officer must limit investments for each trust account to those which conform to the trust instrument's restrictions. O'Boyle, Suitability, CoNfERENCE ON SECURITIES RECuLA'TION 91 (R. Mundheim ed. 1965).

20. COHEN, supra note 19, at 1607-08.

21. It should be noted that "risk" as used here means relative volatility in securities prices as measured against $a$ base index such as the Standard \& Poor's 500. For a discussion of volatility, see Welles, The Beta Revolution: Learning to Live with Risk, INST. INv., Sept. 1971, at 21; IIS REPORT, supra note 2, pt. 2, at 400 (app. to $\$ \mathrm{~F}$ ).

22. CoHEN, supra note 19 , at 1609-11.

23. Harvard Note, supra note 19, at 618-20. 
ties react differently (in direction or degree) to external events, such diversity substantially reduces aggregate portfolio risk..2 Thus, the total return concept is rendered meaningless by self-imposed investment restrictions in some trust instruments, but it is an intelligent and viable test of prudent investment for relatively unrestricted trust accounts. ${ }^{23}$

\section{B. Conflicts of Interest, Interlocking Directorates, Self-Dealing and the Like}

Bank complexes provide a number of services for large corporations, and they may have a variety of relationships with corporate clients whose securities are held as portfolio investments by trust departments. ${ }^{26}$ As a result of the magnitude and variety of these relationships, banks may be faced with opportunities to abuse their potential economic power over their portfolio companies. ${ }^{27}$ Also, the presence of outside directors from industrial corporations on the banks' boards of directors, ${ }^{28}$ and the internal power of industrial corporations having commercial relationships ${ }^{29}$ with the banks, gives corporations power

24. See, e.g., H. Markovitz, Portfolio Selection: Efficient Divensificition of INvestMENTS (1959); CoHEN, supra note 19, at 1611-14. Bejond a certain point, however, increasing the number of holdings has no significant marginal effect on aggregate portfolio risk. Id. at 1613 n.42. Some economists doubt the "justification of increasing portfolio sizes beyond 10 or so securities ...." Evans \&. Archer, Diversification and the Reduction of Dispersion: An Empirical Analysis, 23 J. Finaxce 761, 767 (1968).

This analysis, of course, does not take market liquidity in an individual security into account-investment of the assets of a large employee benefit plan fund or common trust fund in only ten securities would mean intolerably large positions in ten portfolio companies which could be extremely difficult to acquirc or sell. Thus, in practice, large institutional portfolios are commonly diversified bejond the minimum level dictated by diversification theory. IIS REPoRT, supra note 2, pi. 2, at 436 (Table V.11).

25. For thorough discussions of present investment practice, sce C. Euts, Instrru. TIONAL INVESTING 50-64, 142-53 (1971); Welles, The Beta Revolution: Learning to Live with Risk, INsT. INv., Sept. 1971, at 21.

26. Bank officers and directors often serve as directors for corporations which have commercial relationships with the bank and whose securities are held by the trust de. partment for various trust accounts. The bank may also serie as trustec for such a corporation's employee benefit plans, and as registrar, stock transfer agent, or bond indenture trustee for the corporation's stocks and bonds.

27. PatMan RePort, supra note 2, at 1-5.

28. The Patman Report, like the IIS Report, conducted a detailed survey of the forty-nine larger commercial banks in ten metropolitan cities. From this data base, the Patman Report found 768 interlocking directorates with 286 of the $\mathbf{5 0 0}$ largest industrial corporations. PatMan Report, supra note 2, at 3. Similarly substantial interlocking directorates were found between the banks and the fifty largest merchandising, transportation, utility and life insurance companies. Id. The Patman Report recommended that bank officials be prohibited from sitting on the boards of corporations if (I) the corporation's employee benefit plan was administered by the bank, (2) the bank held more than five percent of the outstanding securities of the corporation, and (3) the corporation was a similar competing financial institution. Id. at 9.10.

29. The IIS Report dealt with some of the possible reasons why the fifty largest trus: departments would administer almost seventy percent of the total of all trist assets. While it could not establish cause and effect, the existence of employec benefit fund trust accounts was closely associated with aggregate demand deposits in the bank. In addition, large demand deposits (greater than $\$ 100,000$ ) were more closcly correlated with trust department assets than demand deposits as a whole. IIS REPORT, supra note 2, pt. 
to affect trust department investment decisions. Although bank trust department officials deny that the bank's directors influence investment choices, or that the trust department knows which corporations have significant relationships with the commercial side of the bank, there is evidence that such relationships have been used to influence trust department decision-making. ${ }^{31}$

To prevent misuse of commercial credit information and potential conflicts of interest, many banks have sought to develop a "wall"'s2 separating the trust department from the bank's outside directors, and the commercial department. The Hunt Commission Report has recommended that a "wall" be required only for banks with more than 200 million dollars of trust assets. ${ }^{33}$ However, bank regulatory agencies

2, at 489. In other words, Ford Motor Co., for example, would typically have large deposits with the same bank to which it entrusted its cmployee benefit plan.

The IIS Report also attempted to measure the importance of the corporation's com. mercial relationship to the bank and determine whether the existence of commercial re. lationships between a corporation and the bank increased the likelihood of such car. porations being a portfolio company of the bank. Using three dummy variables, which accounted for the existence of interlocking directorates, geographical proximity, and the bank's management of the corporation's employee benefit plan, the data indicated a positive relationship between the size of a corporation's demand deposits and the amount of its stock held by the bank, and a similar relationship involving loans and bank holdings. IIS REPORT, supra note 2, pt. 2, at 471-75 (Table V-26). For an analysis of the ties with the commercial bank and their relative importance to the company, sce id., pt. 5, at ch. XV. The conclusion which the IIS Report data suggests is that corporatc commercial relationships are important to the bank, that bank employees sensitive to the relative importance of certain commercial relationships may allow that fact to in. fluence their buy, sell, or hold decisions, and that some statistical cvidence exists to support this theory of behavior.

30. One bank executive repeatedly stated that it was absurd for anyone to think he would risk criminal sanctions just to give a specific trust a limited, temporary boost in performance by raiding commercial department files. For a specific statement of onc bank's policy on these matters, see InvestMent MANaGement Grour, First National GitY Bank, The ANatomy of AN INVESTMENT 11 (1971) [hereinafter cited as Citribank 1971 REPORT]:

However, analysts and portfolio managers in [the trust department] are specifically prohibited from seeking confidential customer information which inay be provided to the commercial banking areas of First National City Bank in conjunction with lending activities, just as lending officers are prohibited from providing such information to [trust department] employees. The [b]ank scrupulously main. tains complete isolation of the [trust department] investment activitics from the traditional banking functions.

31. See, e.g., PATMAN REPORT, supra note 2, at 775.83; IIS REPORT, supra notc 2, pt. 5, at 2271-2843. The case studies in the Patman and IIS Reports may generally be charncterized as examples of instances where bank management was willing to ignore its fi. duciary duties to its trust customers to further the interests of its important commercial customers. For example, in one case, when an attractive offer was made for the stock of a railroad company held in trust by a Delaware trust company, the trust company sought to sell the stock for a lower price to two other competing railroad bldders with which it had interlocking directors. PATMan REPORT, supra note 2, at 775.79.

32. See Herman \& Safanda, Commercial Bank Trust Departments and the "Wall," 14 B.C. IND. \& CoM. L. REv. 21 (1972), Bank efforts to create effective "walls" were unquestionably accelerated in the 1960's after the Merrill Lynch/Douglas Aircraft Co. inside information case. Merrill Lynch, Pierce, Fenner \& Smith, SEC Securities Exchungc Act Release No. 8459, [1967-69 Transfer Binder] CCH FED. SEc. L. Rep. 1] 77,629 at 89, 347 (1968).

33. Hunt Commission RePorT, supra note 5, at 101. It was apparently felt by Hunt Commission members that the "wall" was impractical in smaller banks where just one or two persons had line responsibilities in both the commercial and trust departments. 
should consider basing the "wall" requirement on a more effective criterion: the functional separability of the commercial and trust departments. If a bank officer with line responsibility over beth the trust and commercial departments has subordinates in each department who exercise lending or investment discretion, a "wall" between those subordinates should be automatically required regardless of the amount of trust assets. The trust examination should show the trust examiner whether or not the bank has sound procedures which actually prohibit communication between the outside directors, the commercial departments, and the trust departments. In this regard, the trust examiner can educate each bank as to the "wall" policies followed by other banks.

Moreover, in scrutinizing potential conflicts of interest, trust examiners usually receive from banks a list of interlocking directorates involving corporation and bank officers or directors. ${ }^{3 *}$ Thile that list may roughly identify trust department holdings subject to improper external pressure, trust examiners generally are not given a list of those corporations which have significant commercial relationships with a particular bank. Except for those bank examiners who may also examine the commercial side of a bank, trust examiners must rely on rumor and their own "feel" to assess the potential influence of commercial relationships on trust department securities transactions.

The trust examiner should receive a list ${ }^{35}$ of all portfolio corporations having interlocking directorates or "significant" relationships with the bank. Identification ${ }^{37}$ of the trust accounts which hold the securities of these corporations and which grant the bank investment discretion would be the second step. ${ }^{\text {ss }}$ The trust ex-

Others have suggested that since there is less possibility of material inside information in the credit files, and less potential impact of investment actions based upon such information, the adverse effect of not having a wall would arguably be minimal. Miller, Current Developments in Trust Supervision, I11 TRust \& EsTATES 268 (April 1972) [here. inafter cited as CoMptroller Developarents].

34. CoMptroller's MLanual, supra note 16, at 87-94. The national bank examiner is required by the Comptroller's Manual to list "significant" (more than ten percent of the shares outstanding) bank holdings of stock in accounts where the bank has investment responsibility.

35. The bank's commercial department, with review by the commereial deparment examiners, could prepare a list of all significant commercial customers. The bank's board of directors, officers, and employees could submit the names of corporations with which they have officer or directoral responsibilities. Trust examiners could then collate the data submitted to create the list.

36. It would seem reasonable to develop a sliding scale of "signiticance" (rather than some absolute dollar amount) which would sclect out for extended trust examiner analysis only those accounts, whether the bank be large or small, which might have the potential to influence trust department investment decisions in the particular bank.

37. In computerized banks, it may be possible to get a "printout" of stuch accounts. If, instead, labor-intensive methods of selection are necessary, the banks, trust examincrs, and regulatory agencies will need to work out a method of selection which minimizes labor costs and lost man-hours.

38. Because trust accounts over which the bank has no investuncnt discretion cannot be "influenced" in any event, they should not be included on such a list. 
aminer should then focus on the relative performance of such accounts. Their relatively poor performance, if attributable to the securities of the identified corporations, would strongly suggest improper influence on trust department investment choice.

\section{Cash Management}

Balanced against a bank trust department's fiduciary duty to invest the trust account's assets, ${ }^{30}$ overriding liquidity needs may sometimes require leaving parts of the trust account uninvested. Such needs result, for example, from preparing for imminent trust account distribution requirements or postponing investment decisions in anticipation of a better overall market situation. ${ }^{40}$ Banks in major money centers have resolved the dilemma of productivity versus liquidity by creating internally managed short-term securities funds with a corpus of corporate commercial paper or U.S. government short-term securities. ${ }^{41}$ Administratively, bank trust departments subdivide these short-term securities funds into units of participation which are "sold" to individual trust accounts. ${ }^{42}$ Some banks have set a floor on participation in the funds by pricing each unit at $\$ 1000 ; 43$ other banks allow a unit to be purchased only if it will earn enough trust account profit (generally, \$100) to offset the bank's costs. Since the return on commercial paper and U.S. government securities has generally been a point or so less than the prime bank lending rate, short-term securities funds have earned a significantly larger return than the use of savings accounts would have afforded.44

39. 2 ScoTt, supra note 15 , at $\$ 181$.

40. A trust account may temporarily have parts of its corpus uninvested for other reasons: Such parts may be proceeds from the sale of a trust asset awaiting rcinvestment; incoming trust corpus from, for example, life insurance awaiting investment; inconc earned on corpus investments awaiting reinvestment or distribution; and periodic con. tributions from a corporation to fulfill its funding requirements under an cmployec benefit pension or profit-sharing plan awaiting investment.

41. See, e.g., Butler, Starting a Short-Term Securities Fund, 109 Trust \& EsTATes 490 (June 1970); Schneider, Selting Up A Cash Asset Fund: One Bank's Experience, 110 Trusr \& Estates 372 (1971). Unfortunately, there are only a few viable vehicles available for short. term cash investment which provide instant liquidity. United States Treasury bills, which would have liquidity, are currently issued only in round lots of $\$ 10,000$ and thus are unavailable for most individual accounts. Dept. of the Treasury Relcase, Feb. 25, 1970.

42. The unit's price is kept constant for bookkeeping purposes during the tcrm of the short-term securities fund, so that external fluctuations in the interest rate prevailing on the open market do not affect the unit's value and thereby do not cause the unit holder to realize a taxable gain or loss on the unit as a specific investment.

43. The rationale advanced for this price is that participation of at least $\$ 1000$ is necessary to cover the "round trip" cost of getting units of participation in and out of the short-term securities fund. Different banks estimate this cost to be between $\$ 10$ and $\$ 25$ for a "round trip."

44. Besides having a lower rate of return, savings accounts result in a greater measure of illiquidity, since cash must generally be kept in such accounts for a period of onc to three months before interest accumulates. 12 C.F.R. $\$ 217.7$ (1972). 
For trust accounts which do not meet the short-term securities funds participation standards, and for banks without the computer time or mechanical equipment necessary to administer short-term securities funds, the alternative employed most frequently has been to deposit the "uninvestable" cash in the trust department's demand deposit account on the commercial side of the bank complex. Because banks are prohibited from paying interest on demand deposits, ${ }^{\text {t5 }}$ the bank complex "saves" the interest on the cash which might otherwise be deposited in a savings account, and has significantly more money available for commercial department operations. ${ }^{\circ 0}$ The bank complex sometimes gives the trust department, not the individual trusts, credit for the amount saved, thereby increasing the profitability of trust department operations. ${ }^{47}$ Thus, those banks lacking short-term securities funds arrangements sacrifice trust income for liquidity while enjoying the use of the uninvested cash. The Hunt Commission Report has expressed concern that more frequent analysis and review of bank policy may be desirable whenever a bank lacks short-term securities funds or sets minimum participation requirements for such funds at levels too high for some accounts to qualify. ${ }^{48}$

In a bank with short-term securities funds, a bank trust department account manager faces a potential conflict of interest: placing the cash in a short-term securities fund to earn the trust account a return, or placing the cash in the trust department's demand deposit on the commercial side of the bank to improve his department's profitability. Since the trust department's commissions for managing accounts will not be affected, while the net profitability of the trust department

45. 12 U.S.C. $\$ 37 \mathrm{Ia}$ (1940). The Federal Reserve Board has determined in its Regulation $Q$ that "demand deposits" are deposits where the depositor has a legal right 10 receive his deposit back in full in less than thirty dajs. 12 C.F.R. $\$ S$ 217.1, 217.2 (1972). See Hexter, That Which We Call A Deposit ...., 26 Bus. LAw. 69 (1970).

46. The IIS Report found that, for 1969 , the indirect value of demand deposits attributable to trust department relationships, e.g., broker balances, portfolio company balances, and trust department deposits, amounted to thirty percent of direct commission income, or approximately .06 percent of trust department assets. IIS REPort, stupra note 2, pt. 2, at 480,482, 483. For trust department deposits alone, the IIS Reporl estimated that the value of the deposits was worth 26.6 percent of direct commission revenues. $I d$., pt. 2 , at 481 .

47. Credit received from the commercial department can substantially affect the trust department's profitability. According to a survey taken by the Federal Reserve Bank of New York, the trust departments of ten large New York City banks received commercial department credit for deposits for 1971 in the amount of $\$ 114.1$ million. bringing ad. justed net earnings to about $\$ 95.7$ million. Big New York Banks' Corporate Trust Losses Shrank Sharply in 1971, Wall St. J., Sept. 7, 1972, at 21, col. 2.

48. Hunt Commission Rerort, supra note 5 , at 102 . On the other hand, there is a long tradition in trust examinations of focusing heavily on cash management. NerntN, supra note 11, at 54. Uninvested cash is also one highly visible item in a trust cus. tomer's monthly statement from the bank to which all statement recipients an relate, whether they are sophisticated corporate treasurers monitoring pension trusts or housewives monitoring grandparents' legacies. 
may be enhanced, the trust account manager may be improperly influenced, at least on close decisions, to keep the cash in a demand deposit. ${ }^{49}$ To prevent potential conflicts of interest, and to increase productivity without loss of liquidity, regulatory agencies could consider prohibiting trust department deposits on the commercial side of a bank ${ }^{50}$ or seeking legislation to allow payment of interest on demand deposits. ${ }^{51}$ However, a less disruptive remedy would be to require the use of short-term securities funds wherever possible. The trust examiner could educate smaller banks about how to establish their own short-term securities funds based on the experience of larger banks in his geographic region. Shifting more banks into collective cash investment plans would raise the overall return of trust accounts under bank management, thereby making banks more attractive as money managers. Smaller banks could form joint ventures ${ }^{62}$ and thus achieve important economies of scale in the short-term securities markets. In addition, the trust examiner could accumulate technical information which might help banks to reduce substantially the floor for participation in short-term securities funds ${ }^{53}$ and thus extend collective cash investment to all trust accounts regardless of cash balance size. Finally, if internal short-term securities funds cannot be established for cost reasons, bank regulatory agencies should consider requiring the use of external short-term securities funds. ${ }^{54}$

49. In the aggregate, while such cash subject to conflict of interests may total about .76 percent of the total assets under management in the fifty largest trust departments, a relatively insignificant amount to these bank complexes, the cash is still significant in its dollar amount: 1,476,300,000 dollars at the end of 1969. IIS RErorT, supra note 2, pt. 2, at 429 (Table V-4).

50 . Interviewed bank officials suggested that prohibiting the deposit of trust department cash on the commercial side of a bank would only lead to complex "sweetheart" deposits among competing financial institutions. While such arrangements would trans. gress antitrust laws, they would be extremely difficult to discover, police and prove.

51. ROBER'soN, supra note 9, at 675.80; Kreps, Modernizing Banking Regulation, 81 LAw \& ConTEMI.' Prob. 648, 66I (Aug. 1966). Allowing payment of interest on demand deposits would have broad implications. For example, commercial customers (including brokers) who must presently "pay" a fixed price for demand deposits to the bank would not continue to have the concomitant economic power to clemand "free" or discounted services from banks. The Hunt Commission specifically recommended that the prohl. bition against the payment of interest on demand deposits be retained, supra note 5, at 27 .

52. One interesting joint venture has been created by the Citizens and Southern National Bank for the Atlanta area. It organized an investment company whose shares will be purchased for trust customers by other banks and trust institutions of that region which are unable, because of their small size, to administer their own common trust funds. Invesco EQuIrY Fund, INc. Prospectus, August 21, 1972.

53. Rather than setting the floor for participation in the short-term sccurities fund in terms of the investment needed for the bank to break even on the transaction costs, a more useful approach would be to eliminate the floor for participation and charge the trust customer an aliquot share of the costs. One drawback to this suggestion is that the "transaction costs" are not easily identifiable by bank trust departments.

54 . Only quite recently have short-term securities funds been registered with the SEC as mutual funds. Hershey, Overnight Mutual Funds for Surplus Assets, N.Y. Times, Jan. 7, 1973, \$ F, at 5, col. 2. SEC Approves Registration of Mutual Fund Managed by Bank, 190 BNA SEC Reg. \& L. Rep., at A-8 (Feb. 21, 1973). 


\section{Best Execution and Brokerage Allocations for Research}

In securities transactions for accounts without directed brokerage, the bank trust department's trader is bound to seek "best execution." This duty requires the trader to get the best net realized price for a specific security by initiating price inquiries wherever the security is traded, be it the NYSE, regional exchanges," NASDAQ, market, ${ }^{59}$ or the fourth market. ${ }^{60}$ However, trust departments sometimes direct brokerage to certain Wall Street brokerage houses ${ }^{\mathrm{B1}}$ as a

55. "Directed brokerage" is the securities industry's shorthand for trust instruments which contain specific instructions as to where the trust's securities iransactions are to be taken for execution. Personal and corporate agency accounts frequently have such instructions. But employee benefit plans accounts, common trust funds, and large personal estates and trusts generally do not. IIS REIORT, supra note 2, pt. 2, at 437 (Table V-12).

56. "Best execution" relers to the fiduciary duty to place portfolio transactions in such a way that achieves the best result for the trust account. See, e.g., Delaware Man. agement Co., SEC Securities Exchange Release No. 8128 (July 19, 1967). [1966-1967 Transfer Binder] CCH FED. SEC. L. REP. T7,458, at 82,883 (1967); Consumer-Investor Planning Corp., SEC Securities Exchange Act Release No. 8542 (Feb. 20, 1969), [19671969 Transfer Binder] CCH FED. SEC. L. REP. F 77,677, at 83,525 (1969). This phrase implies that the trust department's purchases and sales for its trust customers will be made at the best available price. Best execution means best net realized price in terms of the price per share, the lowest possible commission charge, and various non-price considerations such as execution ability, brokerage commission rate, back office senice, and, perhaps, research commitments. Phillips, Best Execution and Negotiated Rates, Third ANival INstitute on Securtties Regulation 319.20 (R. Mundheim \& A. Fleischer, Jr. eds. PLI 1972) [hereinafter cited as ThIRD ANNuAl INstrrute]. In Mr. Phillips' opinion, best price is the main element of best exccution. Id. at 320 .

57 . Some NYSE-listed securities are dually listed on a regional stock exchange. See, e.g., Loehwing, Wall Street I'est, B.ARRoN's, MIarch 20, 1972, at 3.

58. NASD.AQ, the acronym for the NASD's Automated Quotations System which began in February 1971, is a centralized nationwide electronic over-the-counter auction market system which contains some NYSE-listed securities. Katz, NASD Automated Quotations System, ThIRd ANNUAL INSTrTUTE, supra note 56, at 359 et seg.

59. The "third market" is a specialized scgment of the over-the-counter market which deals in NYSE-listed securities. See SEC, Public Policy Implications of Investment Company Growth, H.R. Rep. No. 2337, 89th Cong., 2d Sess. 159.61 (1966) [hercinafter citcd as PPI]. Because the third market-makers do not have to charge the N'SE fixed minimum brokerage commission rate, when institutions trade in the third market, they usually save a considerable amount of money, IIS REIORT, supra note 2, pt. 4, at 1465.

60. The "fourth market" refers to direct trades between institutions which are not reported on exchange tapes. PPI, supra note 59, at 161 .

61. One constraint on best execution existed before late 1909, when many banks allocated some brokerage according to the size of each broker's demand deposits with the bank complex.

In late 1969, as much as seventy-five percent of "Iree" (nondirected) brokerage com. missions were so allocated. Fiske, How Banks Pass Out Commissions, Inst. Inv., Dec. 1969, at 29 [hereinafter cited as BANk Commssioss?. Based on 1969-1970 data, the IIS Report found a "strong relationship" between bank commission allocations and the size of brokerage house demand deposits. IIS REPORT, supra note 2, pt. 2, at 470 . Persons interviewed by IIS staff suggested that the typical reward ratio of deposits to commissions was ten to one. Id., pt. 2, at 471; B.ANk CommisstoNs, supra, at 35. Obviously, because the demand deposits are so valuable to a bank complex, and because brokerage commissions could attract brokerage house deposits, the more sophisticated trust customers successfully bargained for a zero fee to the bank based on the commissions (and con. sequential brokerage house deposits) that the trust was expected to generate. Id. at 37. However, subsequent to the Justice Department Antitrust Division's complaint that allocating brokerage according to demand deposits violated antitrust laws (Avanicis BANker, Sept. 18, 1970, at 1, col. 1), and under pressure from suits like the one brought 
reward for research received. ${ }^{62}$ When trades are executed on the NYSE where fixed minimum commissions are set above their objective economic value, ${ }^{63}$ banks apparently have a duty to demand some benefit such as research ${ }^{64}$ in return for the excess of the fixed minimum commission over its competitive value. ${ }^{05}$ Best execution under thesc

against Chemical Bank alleging that this practice violated fiduciary principles, Schaffer v. Chemical Bank, [1971-1972 Transfer Binder] CCH FED. SEC. L. REl. 99,408, at 92,014 (S.D.N.Y. 1972), banks voluntarily ended such reciprocal business with brokerage houses. Yet bank trust department officials interviewed by the author suggested thit, while they refuse to consider the broker's commercial relationships with the complex when executing transactions, not all brokers have forgotten how potent their demand deposits once were. For corroborating evidence, see Bleakley, End of an Era?, INST. INV., Feb. 1972, at 27, 30 [hereinafter cited as BLEAKLEY].

In any event, to protect against recurrence of reciprocal practices based on demand deposits between brokers and banks, bank regulatory agencics and trust examincrs should be certain that the "wall" established between a bank's commercial and trust depart. ments extends to the trust department's traders. Again, the trust cxaminer may calucatc the banks which he examines about the "wall" procedures of other banks in the ex. aminer's geographic region. See pp. 982.83 supra.

62. Depending upon the type of trade involved, allocating brokerage as a reward for research may or may not threaten best execution. A routine trade of, say, 100 shares of AT\&T can be handled in a competent manner by virtually every broker, and allo. cating the trade according to research received probably docs not affect best execution of the trade. However, for best execution, a non-routine trade may require cxecution through specific brokers who have special block-trading abilities, and these brokers with special trading skills may not have reputations for excellent research. If a bank sends a non-routine trade to a broker as a research reward without regard to his special abilities, best execution may be lost.

One midwestern bank trust department in the spring of 1972 exccuted all trades for less than 1,000 shares in the third market, all trades for over 10,000 shares through the block-trading specialists. Thus, only trades between 1,000 and 10,000 shares could be used by the trader to reward for research. As the breakpoint for negotiating commission rates is lowered from $\$ 300,000$ to $\$ 100,000$, the area for research reward based on excess in fixed minimum rates will be smaller; and in this bank's system, $\$ 100,000$ will become the new ceiling and 1,000 shares the new floor for allocating brokerage for research. Clearly, this bank's perceived need to reward for research through brokerage commissions may cause it to allocate brokerage to a firm without regard to the avall. ability of better prices elsewhere. See Feuerstein \& Phillips, Reciprocity for Research and for Sales of Fund Shares, THIRD ANNUAL INSTITUTE, supra note 56, at $335,336$.

Trust departments have elaborate methods for calculating the amount of brokerage allocations based on the quality of research ideas, follow up, timeliness, etc. Sec Mattliil, Bank Research in the Age of Negotiated Rates, INST. INv., May, 1971, at 21 [hercinafter cited as BANK Research]; Orth, Analyzing the Analysts: Can Their Performance Really $B_{0}$ Measured?, INsT. INv., Oct. 1972, at 91; Bloom, The Great Money Game, N.Y. Timcs, Jan. 16, 1972, \$ 6 (Magazine) at 10; Best 'Paper Portfolio' Has Appreciated 90\% in Chase Bank's Game, Wall St. J., Oct. 6, 1972, at 18, col. 2. Bank trust departments usually make no effort to segregate brokerage by trust account or collectively-invested fund. Rather, the bank trader may place a prescribed amount of portfolio brokerage transactions with a specific broker without knowing which trust account or collectively. invested fund received the research product, if the prior research purchased has dirccly benefitted any one account.

63. See generally Baxter, NYSE Fixed Commission Rates: A Private Cartel Goes Public, 22 STAN. L. REv. 675 (1970).

64. In exchange for brokerage commission allocations, the banks can get from brokers computer software services, research packages, stock certificate processing and storage, and economic forecasting. See, e.g., BANK COMMISsions, supra note 61, BANK RESEARCH, supra note 62; BLEAKLEY, supra note 61 .

65. While the law is unsettled on this point, courts have moved toward establishing such a duty. See Moses v. Burgin, 445 F.2d 369 (lst Cir. 1971), cert. denied sub nom. Johnson v. Moses, 404 U.S. 994 (1971). In any case, bank trust departments have been advised by counsel of the probable existence of such a duty, and have behaved as if onc clearly existed. 
circumstances may require, in effect, an insistence on research service in exchange for the forced premium paid to brokers as a result of the fixed minimum commissions. As the breakpoint for the application of fixed minimum commissions is reduced and virtually all of the excess disappears, ${ }^{66}$, the duty will be correspondingly obviated. Banks may then argue that they should be allowed to pay for research by adding a voluntary premium to the brokerage execution commission borne by the trust account. The issue will be whether such premium "soft dollar" 6 expenditures should be permitted.

The SEC has indicated that such expenditures are acceptable. ${ }^{.8}$ When it was suggested that legislation was needed to clarify the legality of institutional investors spending premium soft dollars for research, ${ }^{69}$ the SEC affirmed that ${ }^{70}$

[W] hile the obligation to obtain the best security price remains, [an institutional investor] isn't required to seek the brokerage service that carries the lowest cost as long as the difference in cost was "reasonably justified by the quality of the service offered."

66. April, 1974, has been set as the goal for reducing the breakpoint for negotiating brokerage commissions to \$100,000. SEC Sets April 1974 As Goal for Trimming Negotiated-Rate Cutoff to $\$ 100,000$ Level, Wall St. J., March 23, 1972, at 4, col. 2. Ilost in. stitutional-sized trades are between $\$ 100,000$ and $\$ 200,000$. Blcakley, I'here Do W' Go From Here?, INST. INv., Jan., 1973, at 44, 46 [hercinafter cited as Progress Report].

Few institutional-sized securities transactions are smaller than $\$ 100,000$. Thus, when the brokerage commissions of trades greater than $\$ 100,000$ are negotiable, few trades of institutional size will contain the traditional excess in fixed minimum commissions necessary to purchase peripheral services.

67. In the parlance of the securities industry, "hard dollars" are those paid by an institutional investor against its own account. "Soft dollars" are those charged by an institutional investor against individual accounts, such as brokerage commissions on sales or purchases. Thus, services like research bought with the excess in fixed minimum brokerage commissions are known as soft dollar services, viz., soft dollar research. The term "premium soft dollars" is uscd here to mean a soft dollar payment for research added onto a negotiated soft dollar payment for bare exceution, which together become the total brokerage commission charged for execution of the securities iransaction.

68. The SEC has commented:

Concern has been voiced that under such circumstances institutional managers charged with a fiduciary duty would be reluctant to pay a higher commission rate which reflected research. The Commission belieres that they should not be. In our opinion, the providing of investment research is a fundamental element of the brokerage function for which the bona fide expenditure of the beneficiary's funds is completely appropriate, whether in the form of higher commissions or outright cash payments.

SEC, Statement on the Future Structure of the Securities Markets (Feb. 2, 1972), 137 BNA SEC. REg. \& L. REP. pt. 2, at 7 [hereinafter cited as Furure Structure Statement].

69. Institutional Investors Say They May Need Clarifying Legislation, Wall St. J., April 18,1972 , at 4 , col. 3 .

70. Applicability of the Commission's Policy Statement on the Future Structure of the Securities Markets to Selection of Brokers and Payment of Commissions by Institutional Manager, SEC Investment Company Act Release No. 717 (AIay 9, 1972), [1971-1972 Transfer Binder] CCH FED. SEC. L. REP. 9 78,776, at 81,631 (1972); SEC Say's Institutions Must Seek Best, Not Always Cheapest Broherage Services, Wall Si. J., Alay 10, 1972, at 2, col. 4. Address of Chairman William J. Casey, Quality Serice in Brokerage, before Securities Industry Association, New York, Oct. 11, 1972. 
However, several arguments against such expenditures can be made. ${ }^{71}$ First, because brokers do not specifically charge for research, trust beneficiaries cannot calculate how much of any brokerage commission was paid for this service. Second, the benefit of research is rarely traceable to specific trust accounts, and the ratios of benefits to costs may be very different among individual accounts. Third, each trust already pays a commission to a bank for its trust department's services which supposedly includes a charge for investment research. Thus, when research is purchased with brokerage commissions, individual trust beneficiaries in effect may unknowingly pay twice for research expertise. Finally, since the bank is not paying its own money for the research, it has little incentive to drive a hard bargain for the research element in the commission. Mounting evidence suggests that few banks (or other institutional investors) would pay hard dollars for research. ${ }^{72}$

Since banks apparently find Wall Street research a useful and desirable input, bank regulatory agencies must determine whether hard dollars should be required in payment. ${ }^{73}$ Even if premium soft dollar purchases are allowed, customers certainly deserve full disclosure from the bank with respect to its practices. ${ }^{74}$ But it is difficult to see how the bank regulatory agencies could conclude in a manner consistent with sound fiduciary principles, ${ }^{75}$ that any sort of premium soft dollar payment for research should be allowed after the fall of fixed minimum brokerage commissions. There is no logical reason why a bank could not pay hard dollars for research services and raise its own commission fees to cover the additional expense. This action would force banks

71. Other commentators have also been dissatisfied with the SEC's position. See, e.g., Address of David Silver, General Counsel of the Investment Company Institute, FBA.CCH 1972 Conference on Mutual Funds, March 15-18, 1972, reprinted as Silver, The SEC and Mrutual Fund Brokerage: A Continuing Regulatory Enigma, 144 BNA SEc. REci. \& L. ReP. at D-1 (1972); Eisenberg, Mutual Fund Litigation, 5 Rev. SEc. Rec. 909 (1972); Progress Report, supra note 66, at 47. Bleakley, John C. Bogle: A Wellington Whiz Kid Grows Older, INsT. INv., June, 1972, at 63, 98:

[A]llowing people to pay extra soft dollars just opens the door to abuses. Who is to say how much extra you can pay? It is just unenforceable.

72. Progress Report, supra note 66, at 47. BANk RESEARCH, supra note 62, at 25.

73. The alternative would be for the courts to resolve the "law" of premium soft dollars for research. A number of costly suits could be instituted against banks possessing different policies, at much greater cost to such banks than if the bank agencies settled the issue.

74. While Senator Harrison A. Williams, Jr., Chairman of the Subcommittec on Securities, Senate Committee on Banking, Housing, and Urban Affairs, has joincd the SEC in its view on soft dollar expenditures, he did so on the condition that the mutual fund advisory contracts would provide for such payments and such contractual provisions would be clearly disclosed to the mutual fund shareholder. Institutional Membership and Broker Fees Treated Jointly in Bill Sen. Williams Plans, Wall St. J., Scpt. 8, 1972, at 4, col. 3-4.

75. 2 Scotr, supra note 15 , at $\$ 170.17$ (Use of Trust Property for Trustec's Own Purposes). 
and their trust customers to evaluate the bank's own research potential. It would also make customers aware of the amount they had to spend over and above the trust commission for outside research.

Once bank regulatory agency policy with respect to research has been established, examination procedures should scrutinize the banks' "wall" practices to insure that the trust department trader will not know which broker's research services are purchased. The trust examiner again may educate a bank trust department about the "wall" policies adopted by other banks in his examination region.

Finally; the trust examiner and bank regulatory agencies should encourage bank trust department officials to develop a comprehensive definition of best execution. ${ }^{76}$ However, the quantity of securities transactions executed by banks would make it impossible for the trust examiner to scrutinize each transaction for best execution. Gross comparisons to the execution patterns of other institutional investors are not useful in determining a standard for best execution because other investors have very different purposes and characteristics.it But the trust examiner should be more sensitive to consistent patterns of avoidance of particular markets or brokers by traders when he reviews

76. Some mutual fund boards of directors have appointed committees of independent directors to develop a comprehensive definition for best exccution for the mutual fund's traders to follow. Nutt, $A$ Siudy of Mutual Fund Independent Directors, 120 U. PA. L. REv. 179,257 (1971). In the case of trust departments the regulatory agencies could, of course, preempt the bank's business judgments and formulate a best execution definition of their own. Considering the philosophy expressed by Dean Miller, Deputy Comptroller of the Currency for Trust, however, it is not likely that this will happen. Ste p. 179 supra. To acquire better trading advantages and chlance the aggregation or bunching of trading should be encouraged. Since bunching is difficult to accomplish at the trading stage, procedures should be adopted by banks to increasc the aliareness of barious account managers within the bank to the possibility of bunching orders or executing in-house crosses. See BANK RESEARCH, supra note 6:, at $* 3$.

77. Bank trust examiners could compare aggregatc mutual fund statistics and ag. gregate bank execution choices for certain trust accounts. Such a comparison would theoretically focus on the relative avoidance or use of specific markets as between the two financial institutions, and thus provide the examiner with gross execution comparisons. However, the overall pattern of mutual fund portfolio securities executions may not be sufficiently comparable to those of certain bank trust department accounts to provide such a "model." Banks historically have traded in greater quantities of securities and in smaller share orders sizes than mutual funds. IIS REront, supra note 2., pt. 4, at 2169 (Table XIII-7). On the other hand, mutual fund advisors have historically used brokerage allocations in part as a reward for brokerage house mutual fund sales efforts. Glazer, $A$ Study of Mutual Fund Complexes, 119 U. PA. L. REv. 205, 252-59 (1970). Also, some mutual funds have created affiliated regional stock exchange broker-dealer subsidiaries to recapture brokerage commission dollars. Id., at 247-50; Nitt, $A$ Study of Mutual Fund Independent Directors, supra note 76. Finally, banks execute securities transactions which terminate a trust's existence in contemplation of final distribution and apparently engage in more in-house crosses than mutual fund complexes. Compare, 12 C.F.R. § 9.12(d) (1972), with 17 C.F.R. § 270.17a-7 (1972). Howeier, at some future point, gross execution comparisons between financial institutions may be possible. Compare Rule 19b-2, 185 BNA SEC. REG. \& L. REr. at F-I el seq. (Jan. 17, ly73) and SEC Statement on the Adoption of Rule $19 \mathrm{~b}-2$ Governing the Utilization of Exchange Ifcm. bership for Public Purposes, 185 BNA (part ii) (Jan. 17, 1973) with Future SmucturE StATEMENT, supra note 68, at 7. 
monthly transaction reports from traders categorizing all securities transactions by broker, exchange, cost, and type of commission (fixed or negotiated).

\section{E. Advising Multiple Clients}

Since bank trust departments render investment advisory services to a variety of clients, ${ }^{78}$ there is a distinct danger that they will favor some accounts over others in information and trading allocation. For example, because a corporation's selection of a bank as trustee for its employee benefit plan funds is revocable, ${ }^{70}$ and because the corporition can be expected to monitor the fund's performance carefully, a bank may pay more attention to its account than to the typical estate or personal trust. ${ }^{80}$ Furthermore, banks in major money centers have begun to offer the investment advisory services of their trust departments to other banks-correspondent banks of their commercial departments and non-competing "country" banks, i.e., those outside central financial areas. ${ }^{81}$ They have also begun making available such services-through subsidiaries or holding companies-to the general public, $^{82}$ and open- or closed-end investment companies. ${ }^{83}$ Since the sale of investment advisory services to outsiders generates additional income, trust department personnel may feel some pressure to attract more external customers by favoring them over trust accounts in allocating information and trading opportunities. None of the trust ex-

78. For a discussion of the variety of clients a bank trust department may have, sec IIS REPORT, supra note 2, pt. 2, at 420-38.

79. Some corporations designate a bank as trustee but give the investment responsibilities to an outside investment adviser.

80. Corporations establishing cmployee benefit plans gencrally give the bank solc investment discretion, IIS REPORT, supra note 2, pt. 2, at 432 (Table V.7), sole voting authority, id., pt. 2, at 438 (Table V-13), and do not designate brokeragc, id., pt. 2, at 437 (Table V-12). Of the forty-nine banks in the IIS Report survey, sixty-five percull of their employee benefit plan accounts are less than $\$ 50,000$ in value. On the otlicr hand, thirty percent of their employee benefit plan accounts exceed $\$ 500,000$.

81. See E. Herman \& C. Safanda, Bank Trust Department Investment Services for Correspondent Banks and Other Subscribers, July 1972 (unpublished paper on file at the Yale Law School Library). Generally, correspondent banks are banks located in different money centers which provide services for each other. Country banks are non-moncy center banks which may utilize the services of money-center banks.

82. Some of the nation's leading financial institutions, including Chase Manhattan Bank, Bankers' Trust Co., First National City Bank, and Bank of America arc adopting this practice. See, e.g., Fiske, The Banks Fight Back, INST. INV., April, 1972, at 41 [hereinafter cited as FISKE]; Chase Manhattan Corp. Plans Unit to Handle its Trust Management, Wall St. J., April 20, 1972, at 15, col. 2. Bankers' Trust Plans to Set $U p$ Investment Advisory Unit in Florida, Wall St. J., Sept. 25, 1972, at 6, col. 1; Advertisement of BA Investment Management Corporation, Wall St. J., Oct. 2, 1972, at 21, col. 2.

83. On January 24, 1972, the Board of Governors of the Federal Reserve System amended its Regulation Y, 12 U.S.C. $\$ 225.4$ (a), effective February 1, 1972, to allow bank holding companies to act under certain circumstances as investment advisors to investment companies, including mutual funds. [1971-1972 Transfer Binder] CCHI Fev. SEC. L. REP. If 78,503 , at 81,091 (1972). 
amination forms or manuals used by trust examiners deals with the conflict of interest problems raised by the rendering of investment advisory services to multiple clients. ${ }^{84}$

One prime occasion for favoritism among clients is the division of opportunities to purchase or sell "scarce" securities among trust accounts. For example, several account managers may desire a particularly attractive new issue for their trust accounts, but the trust department trader may only be able to get commitments for thirty percent of that amount from the new issue underwriting syndicate. Or several account managers may want to sell a specific security at the same time, but the trader may only be able to get block positioners or third market-makers to accept sixty percent of the shares being offered. Whether the security scarcity arises from market illiquidity, new offerings, or block transactions, fair allocation of investment opportunities among all clients requires the establishment and disclosure of trading allocation formulas. ${ }^{85}$ The bank trust examiner could check adherence to this policy by spotchecking allocations.

Another prime occasion for account favoritism is the allocation of investment information in the form of internal and external research, or market information. ${ }^{86}$ The selection, sequence, and timing of allocation are critical to clients. While certain kinds of unequal allocation are common, securities law does not clearly state a duty to make information equally available. ${ }^{87}$ Preferential disclosure to a few clients by

84. The Comptroller's Manual advises its trust examiners that the sale of investment advisory services means the bank is acting in a fiduciary capacity with respect to its subscribers, and thus may be performed only by banks with trust powers. Cosirmolnen's Masuat, supra note 16, at D-1. Interviews with bank regulatory officials revealed that trust examiners generally review the investment advisory service package materials only for improper inclusion of sensitive or confidential data.

85. A fiduciary may act simultaneously in one transaction as the agent for several clients if all of the parties understand the situation to be so and if the agent subsequently deals fairly with those clients. RESTATEMENT (SECOND) of ACEvCY $\$$ S 390.94 (1958). Either full disclosure or custom can provide the "understanding" as among the various clients. Henderson, Conflicts of Interest for the Mloney Manager, Turp ANkUAz INsTrTuTE, supra note 56, at 293. The SEC may believe an allocation policy is essential: item 1.33 of Form N-IR which must be submitted by mutual funds to the SEC asks the investment advisor of an investment company to state its trading allocation policy. 3 CCH FED. SEC. L. REP. 51,963, at 39,852-53. For a description of the allocation formulas used in some mutual fund complexes, see GLAZER, supra note 76, at 237-41.

86. The best Wall Street research has long gone first and sometimes exclusively to large institutional investors. For example, Merrill Lynch gives expanded research information, technical market memos, market information, etc., first to institutional investors. In some branches, Merrill Lynch keeps all research for institutional use for two weeks, then gives it to the registered representative in the branch. Loomis, The Merrill Lynch Bull is Loose on W'all Street, ForTuNe, MFay, 1972, at 174.

87. Some commentators believe that the custom of prefcrential information alloca. tion is legal because that is the reasonable expectation of the customers. FInST ANiviL INsזITUT, supra note 19, at 333 (remarks of Arthur Fleischer, Jr. \& Lconard Leiman); Third ANNuAL Institute, supra note 56, at 307-12 (remarks of Gordon Henderson). For a contrary view, see ThIRD ANNUAL INSTITUTE, supra note 56, at 310 (remarks of Mejer Eisenberg). 
a broker prior to publishing a market letter has been condemned by the New York ${ }^{88}$ and American Stock Exchanges, ${ }^{80}$ and the SEC. ${ }^{00}$ Similarly, preferential disclosure of material changes from prior investment advice arising from research has been disapproved. ${ }^{11}$ Yet courts have not yet defined a general standard for information allocation. ${ }^{02}$ Preferential allocation might be upheld on a rationale of customer consent implied from prior bank disclosure ${ }^{33}$ or custom. ${ }^{04}$ But analogies from securities law suggest a better guideline: substantial equality, at least within classes among clients.

Under such a standard banks would be expected to make information available to all clients of the same class at the same time and in identical form, to the extent practicable. As a minimum, each bank should require banks to establish a fair and equitable formula for allocation, combined with detailed disclosure thereof to all customers. ${ }^{05}$ Banks should also obtain written acknowledgment that customers understand and agree to the formula. A bank trust examiner could then spot check for bank adherence to its information allocation policy.

88. NYSE, M.F. Circular No. 170, Nov. 16, 1962; NYSE, Guidelines for Member Firm Communications with the Public 5 (1970).

89. ASE, Info. Circular No. 51-71, April 30, 1971.

90. Fin. Anal. Fed., Corporate Disclosure and Insider Information 15 (1968) (remarks of Commissioner Philip A. Loomis, Jr.).

91. See Future STRUcture Stitement, supra note 68, at 6; and Butcher \& Shcrrerd, SEC Securities Exchange Act Release No. 9894 (Dec. 11, 1972) (Findings and Order Imposing Remedial Sanctions) [1971-1972 Transfer Binder] CCH FED, SEC. L. REl. 9 79,135 , at 82,460 (1972). See Butcher \& Sherrerd Penalized on Tips on Penn Central, Wall St. J., Dec. 13, 1972, at 2, col. 2. For a contrary view that the Butcher \& Sherrerd casc if applied universally is "beyond current expectations and standards," see Tillob ANNuAL INSTITUTE, supra note 56, at 308 n.25 (remarks of Gordon Henderson).

92. In Securities and Exchange Commission v. Capital Gains Research Bureau, Inc., 375 U.S. 180 (1963), the Supreme Court held that the SEC may obtain an injunction compelling a registered investment advisor to disclose its practice of purchasing for its own account just prior to publishing a market letter recommending the investment and then immediately selling its shares upon the rise in the market price following the recommendation.

93. ThiRd ANNuAl INSTITUte, supra note 56, at 305 (remarks of Commissioncr Philip A. Loomis, Jr.).

94. For a discussion of different types of policies used by mutual fund complexes and investment advisers for information allocation, see GLAzER, supra note 76, at 219.26; T111k0 ANNUAL INSTITUTE, supra note 56, at 301 (remarks of Gordon Henderson).

95. Where soft brokerage dollars are used to acquire Wall Strect rescarch, conceptilally the bank has an asset (e.g., the research) which "belongs" to all of its trust accounts for which it has executed securities transactions. Since tracing the research asset purchased back to individual accounts is virtually impossible, it may be regarded as an indivisible asset belonging to all the accounts. If the trust department sells cxternally created, undigested Wall Street research bought with brokerage commission dollars, the trust accounts would have a good case for recapturing the research salc procects on the ground that the trust department was illegally selling trust assets in breach of its ffduciary duties. 2 ScoTr, supra note 15 , at $\$ 170.17$. See also Provident Management Corp., SEC Securities Exchange Act Relcase No. 9028 (Dec. 1, 1970), [1970.1971 Trans. fer Binder] CCH FED. SEC. L. REP. T 77,937, at 80,083 (1970). (Officers and dircctors of an investment adviser entered into reciprocal agreements to recapture and retain commissions from the mutual fund's portfolio transactions; this was held to be a breach of fiduciary duty and antifraud provisions of the securities laws.) 


\section{F. Size of Holdings and Concentration Limitations}

As a result of sizeable bank trust department holdings in a single security, a bank may acquire potential control over major corporntions. ${ }^{96}$ Representative Wright Patman, Chairman of the House Committee on Banking and Currency, has proposed a ten percent absolute limitation on a bank's trust department's holdings in a publicly held corporation. ${ }^{97}$ However, the wisdom of this limit has been questioned, ${ }^{98}$ and Patman's ten percent limitation seems arbitrary and unwise for several reasons. First, liquidity considerations generally are not served by a limit allowing such large holdings; a much lower level is already observed by most banks. ${ }^{20}$ Second, the Patman limit fails to take account of investment discretion, which is essential to banks' potential influence on portfolio companies. An accurate indicia of the bank's power over a portfolio corporation is thus not necessarily the total amount of its holdings, but the amount over which it has discretion. Third, banks often receive trusts, some restricted, with large holdings of a particular security; if an absolute ceiling were im-

96. PatMan Report, supra note 2, pt. 1, at 9.

97. H.R. 5700, 92d Cong., Ist Sess., $\$ 13(2)$ (1971). The securities lavs do not constrain aggregate investment in one security. Section 13(d)(1) of the Securities Exchange Act of 1934 , 15 U.S.C. $\$ 78 \mathrm{~m}$ (d)(1) (1971) requires the disclosure by a "group," when the members of the group acquire shareholdings in a corporation of five percent or more. However, except to the extent a bank trust department constitutes a "person" under sections 78(d) and 79(d), because bank trust departments do not have beneficial ownership of the shares which they hold in trust, they are not subject to the disclosure provisions even though their securities holdings in the aggregate greatj; exceed the triggering level. Unless the trust accounts were aggregated to constitute a "group" for purposes of these sections, no disclosure would be required.

98. Hearings on H.R. 5700 Before the House Committee on Banking and Curreng, 92d Cong., lst Sess., pt. I, at 117 (1971) (remarks of Richard B. Smith, then Commissioner, Securities and Exchange Commission), at 129 (remarks of William B. Camp. Comptroller of the Currency). See also C. Golembe, L. Desirmz and G. Fiscien, The Ecosomic Power of Commercial Banks 155.58 (1969).

99. Furthermore, the larger the aggregate position taken by the bank in a portfolio company, the greater is the discount taken when the block is sold, and the more difficult it is for the bank to turn a profit. Such a discount is alled an illiquidity discount. C. Eilis, Instrtutional Investing 85 (1971). Bleakley, Illiquidity: Is It Becoming a Prob. lem Again?, INST. INv., Sept., 1972, at 42. In disclosing First National City Bank's 1971 investment performance record, Executive Vice President Thomas $C$. Theobald was questioned on the fact that none of FNCB's largest stock holdings exceeded five percent of the issuer's common stock. Responding to the implication that five percent was a limit chosen by FNCB to avoid any disclosure problems, Mr. Theobald stated: "[T] hat certainly wasn't our primary reason. If we hold more than five pereent of a company"s stock, we'd be concerned that we could become locked in; that five percent limit is our working rule for good market liquidity." The Money Men, Forbes, April 15, 1972, at 44.

Of course, the liquidity problem is only a real threat to accounts with large blocks over which the trust department has discretion. Large blocks held by the bank without investment discretion make up part of the aggregate total holdings, but are irrelevant to the liquidity question because the bank is not responsible for the timing of the sell decision, only for best execution by the trader when the moment comes. Thus, when discretionary and non-discretionary blocks are aggregated for purposes of calculating constraints, the total holdings may well exceed the constraints, while those accounts over which the bank exercises control are comfortably within any disclosure or liquidity needs. 
posed, diversification of either the incoming trust or other trusts would be compelled, and capital gains taxes would result. ${ }^{100}$ Alternatively, the chosen bank would have to refuse the proffered trusteeship, thereby compelling the trust settlor, the estate's executor, or the trust's beneficiaries to seek another bank.

Better percentage limitations than Patman's can be proposed. Consideration of diversification and market liquidity support a prohibition on any bank trust department holding more than five percent ${ }^{101}$ of the outstanding securities of a publicly held corporation, aggregating trust accounts over which the bank has complete investment discretion. To avoid even the appearance of control, the aggregate holdings of the entire trust department (including all accounts regardless of investment discretion) should not exceed twenty-five percent of the outstanding securities of a publicly held corporation. ${ }^{102}$

Another concentration problem concerns the number of shares in one security which the trust department may hold for a specific trust. The Comptroller's Manual indicates that investment concentration in a portfolio company is undesirable at some degree for all trust accounts. ${ }^{103}$ It suggests as a general rule that not more than twenty percent of the principal of a trust account should be invested in any one company. ${ }^{104}$ The Comptroller's Regulation 9, which governs all com-

100. Forced diversification would not drive the bank into purchasing more desirable securities, since the ten percent ceiling on those securities would have been the first ones to have been reached. Ultimately, forced diversification, after scveral tiers of less and less desirable stock were exhausted, would simply require investment in the least desirable, perhaps unsuitable, securities.

101. While any percentage trigger point is somewhat arbitrary, this figure corresponds to the requirement for SEC disclosure when any person becomes the bencficial owner of five percent or more of a registered company's stock. 15 U.S.C. $\$ 78 \mathrm{~m}(\mathrm{~d})(1)$ (1971). See note 97 . The rationale for the disclosure requirement is that other shareholders have the right to know of persons seeking control or a large concentration of a corporation's stock. This policy behind the disclosure requirement may apply to the trust investment situation. When a bank trust department is granted unlimited discretion over the trust accounts in question, it is similar to persons holding five percent or morc of a corporation's stock because such a bank can control a corporation to the dissatisfaction of other stockholders. In fact, trust departments may need a greater restraint than disclosure because they enjoy greater freedom of action in controlling a corporation to further their own interests (see note 31): they have no direct financial interest in the results since they are using someone else's money.

102. As indicated by bank officials in interviews, the examples of non-discretionary concentrations in one security were DuPont, Mellon, Ford, or Disncy typa family cstates or trusts. Rarely did these types of families own more than twenty percent of the out standing shares of a NYSE listed company. Thus, if no more than five percent could be held by the bank for trust accounts for which it has investment discretion, the twenty percent additional safety margin would allow for trust accounts over which the bink has no investment discretion, and would avoid the unfairness of required diversification. See p. 995 supra.

103. Comptroller's Manual, supra note 16 , at 78.79 .

104. Id. The Comptroller's Manual exempts from this general rule investment con. centrations received in kind from the grantor of the trust, retention of which is specifically authorized. Id. The IIS Report found that in the fifty largest trust departments sixteen percent of the personal trust accounts with equity holdings above $\$ 5$ million held securities of only one company. IIS REPORT, supra note 2, pt. 2, at 465. 
mon trust fund investments, ${ }^{105}$ provides that the market value of a common trust fund's investment in any one portfolio company may not exceed ten percent of the market value of the fund. ${ }^{100}$ However, regardless of the type of trust involved, uncontrollable market fluctuations or other external factors causing changes in securities values can cause excessive investment in a single security, and thus, should not trigger punishment from trust examiners. Rather, a bank should be allowed a reasonable period for restoration of the offending account to normalcy ${ }^{107}$ Violations due to deliberately excessive purchases by the bank should be corrected as quickly as possible and should be subject to normal bank agency criticism.

Finally, some additional limitations on bank trust department securities concentrations are necessary and desirable. In trust accounts, a bank should not be permitted to hold or vote shares of its own stock, stock of its affiliates, or stock of its parent bank holding company. ${ }^{108}$ The effect of such practices might be to perpetuate a bank's management; and other types of corporations are similarly precluded from engaging in them. ${ }^{109}$ Explicit amnesty might be granted ${ }^{10}$ for violations due to preexisting trust agreement provisions, and a ten year period allowed for gradual liquidation of bank stock holdings. ${ }^{111}$

105. Common trust funds are personal trusts and estates accounts which have been collectively invested in accordance with the provisions of $\$ 18$ of the Comptroller's Regulation 9, 12 C.F.R. $\$ 9.18$ (1972). Unless they are operated in accordance with Regulation 9 , they are taxed as separate entities under $\$ 584$ of The Internal Revenue Code of 1954 .

106. 12 C.F.R. $\$ 9.18(\mathrm{~b})(9)(\mathrm{ii})$ (1972). Employee benefit group funds are specifically exempted from this limitation, 12 C.F.R. $\$ 9.18(\mathrm{~b})(9)$ flush language (1972), probably because a high percentage of the securities portfolios of such plans is invested in the stock of the grantor or an affiliated company of the grantor. IIS REront, supra note 1 , pt. 2, at 426 .

107. Proposed modifications to Regulation 9 would provide the trust department vith operating flexibility in correcting temporary excessive investments. Covirriouler DEvelopaENTs, supra note 33 , at 343 . The bank would be allowed tirelie months after such fluctuation during which to reduce the value of the holdings from the excessive amount back to ten percent. Id.

108. For one bank's policy, see CITIBaNk I971 REIORT, supra note 30, at 19:

No First National City Corporation ["FNCC"] stock is purchased by" the Bank in its various capacities without specific direction by the bank's customers. Further, where [FNCC] stock is received in an account at the time a relationship is established with FNCB, such stock is held only if there is a specific agreement in the underlying trust or agency agreement that provides for maintenance of the holding and indicates that the Bank has no discretionary powers over such holding. The Bank does not vote any shares of [FNCC] stock.

109. I G. Hornstein, Corporation Law ANd Practice \$ 311 (19j9); H. BallantiNe, Ballantine on Corporations $402-03$ (rev. ed. 1916).

110. The Comptroller's Regulation 9 already provides that a bank may engage in a self-dealing transaction with a trust account where required to do so by the Comptroller, 12 C.F.R. \$ 9.12(b)(4) (1972). Presumably, since not cren sclf-dealing would necessitate the liquidation of holdings, bank regulatory agencies could unilaterally grant the necessary immunity from regulatory criticism.

111. Bank stocks have notoriously illiquid, thin markets. Massive liquidation of holdings by banks would ruin the market in banks' stodks for innocent shareholders. Ten years is a reasonable time period to liquidate holdings slowly and avoid unnecessary and undesirable price fluctuations. 


\section{New Regulation: Public Reporting of Certain Investment Activities}

Notwithstanding the measures recommended above, which existing rule-making power can effect, increased public disclosure of institutional and bank trust activity will be necessary to significantly improve the present regulatory framework. The Patman Report, ${ }^{112}$ the Banking Reform Act of $1971,{ }^{113}$ the Institutional Investor Study Report, ${ }^{114}$ and the Hunt Commission Report ${ }^{115}$ have all proposed that bank trust departments make public certain information about their securities transactions and their portfolio management. These recommendations generally have designated the SEC to receive and process the new data because much of the information ${ }^{110}$ would relate to the impact of institutional investors on securities markets and portfolio company affairs.

The present system of haphazard reports does not provide sufficient information about institutional investing to enable individual in-

112. With the potential economic power of institutional investors as its touchstonc, the Patman Report recommended for consideration: (1) annual disclosure by bank trust department of aggregate holdings of securities; and (2) disclosure by bank trust depart. ments of all proxy voting of portfolio securities of corporations registered with the SEC. PATMAN RePORT, supra note 2 , at 9.

113. Section 12 of the Banking Reform Act of 1971, based on the Palman Report recommendations, would have required all insured banks to report annually and pub. licly to the FDIC a list of all securities (aggregated without regard to investment responsibilities) held in a fiduciary capacity. It also would have required a public report indicating the extent and use of its voting authority. H.R. 5700, 92d Cong., 1st Sess., $\$ 12(1971)$.

114. The SEC recommended to Congress that the Exchange Act be amended to provide the Commission with authority "to require reports and disclosures of such holdings and transactions from all types of institutional investors. IIS REPORT, supra note 2, pt. 1 , at XI. The SEC proposed ownership of five percent of the outstanding shares of a publicly held corporation as the threshold for the securitics transaction and voting dis. closure. Id. at XXX. Slightly more than one month after the IIS Report was released, Commissioner Richard B. Smith criticized $\$ 12$ of H.R. 5700 's disclosure provisions as being too narrow: $\S 12$ only required annual reports of aggregate bank holdings, not transactions in securities as well. Hearings on H.R. 5700, supra notc 98, at 114, 128 . (Statement of Richard B. Smith, then Commissioner, Securities and Exchange Commission.)

115. Concerned that some financial institutions are subject to a more searching level of disclosure than others, the Hunt Commission Report recommended that corporatc fiduciaries be required to file with "the appropriate regulatory agency" a report detail. ing: (l) the twenty largest stock holdings, in terms of market value, unless it does not exceed $\$ 10$ million; (2) all holdings which constitute five percent or more of the out standing shares of a corporation registered with the SEC; (3) dollar values with respect to each holding broken down into categories reflecting the degree of voting responsibility: (4) interlocked officers or directors with portfolio companies in the voting category where the bank has sole responsibility, and (5) instances where the bank voted against management. HUNT CoMmission REPORT, supra note 5, at 102.

116. While much information is presently available to trust cxaminers, since they are concerned only with the banking aspects of the data, they do not actively collect or publish it. Indeed, the Deputy Comptroller of the Currency for Trusts does not belicve that a good case has yet been made for the collection and publication of data on ccrtaits bank trust department investment activities. Miller, Fiduciary Guidelines for the Sev. enties: Where Are We Headed?, 110 Trusts \& Estates 741, 742 (1971). 
vestors or institutional directors to compare intelligently the investment objectives, portfolio turnover, or past performance of competing institutions. Increased information would help maintain liquid, efficient capital markets for investors by facilitating the brokerage community's anticipation of institutional investing trends. Greater publicity would also help deter illicit activity.117 Finally, greater disclosure would facilitate the study of two of the SEC's chief concerns in recent years-the future structure of the securities markets and the behavior of institutional investors as shareholders. ${ }^{118}$

The new information on securities market structure should specifically include:

(1) turnover rates for different institutional investors;

(2) holdings of different institutional investors;

(3) changes in the level and nature of transaction volume in each market;

(4) changes in the liquidity and "float" in specific securities;

(5) changes in the volatility of prices in securities favored by institutional investors as compared to the volatility of all securities; and

(6) the volume and dispersion of private placements among institutional investors.

With respect to institutional investors' behavior as shareholders, disclosure should include:

(1) voting patterns of different institutional investors;

(2) degree of interference in portfolio company affairs, such as mergers and tender offers; and

(3) interrelationships with portfolio companies and their affiliates which would suggest potential conflicts of interest.

The first step towards public disclosure of bank trust investment activities is to determine which fiduciary relationships held by banks should be subject to the securities transactions reporting provisions. ${ }^{110}$

117. See L. Brandeis, Other People's Money and How the B.ANkers Use It 93 (1914).

118. Future Structure StateMeNt, supra note 68.

119. There are indications that bankers and some members of Congress are willing to concede that public disclosure of certain elements of bank trust department investment activities is inevitable. See, e.g., Securities Underwriters, Mrunicipals Firms May Be Reviewed by House Unit, Moss Sajs, Wall St. J., Nov. 10, 1972, at 3, col. 2. Byrne, Trust Departments, Patman Cool Dispute Over Disclosure, Conflict of Interest Rules, AwER. BANker, Jan. 24, 1972, at 1, 23. 
Trust accounts over which the bank does not have investment discretion $^{120}$ and all personal trust and estate accounts not managed collectively ${ }^{121}$ might be excluded. Quarterly reports should be required for all the remaining trusts, common trust funds, pension funds, and group employee benefit funds. Disclosure should include all significant securities purchases, sales, markets used, and quarterly holdings. ${ }^{122}$ In addition the reporting trusts should disclose quarterly the market value and size of all securities holdings which, after aggregation within each trust group, exceed five percent of the outstanding shares of any corporation. ${ }^{123}$ Finally, all banks administering trust assets should report annually ${ }^{124}$ their 100 largest securities holdings, their portfolio proxy policy, and their investment management policies. ${ }^{125}$

120. These situations obviously involve extremely different family situations which would be difficult to reduce to distinct, tightly homogeneous categories for reporting purposes. Moreover, if held directly by the beneficiaries (rather than by the bank as trustec), these accounts would not have been subject to disclosure. It does not scem appropriate to compel disclosure simply because the bank is administering the investment portfolios.

121. In non-discretionary accounts, the bank cannot affect the timing or sequence of purchases or sales. A middle ground on the way to complete discretion may consist of furnishing investment advice to a co-fiduciary. Whether this middle ground carries abuse potential can only be determined by an analysis of the individual co-fiduciary's invest. ment decision-making. Though a bank might attempt to circumvent the proposed disclosure provisions by asking grantors to create insubstantial "straw" co-fiduciaries, SEC rule-making (backstopped by securities law antifraud provisions) should be sufficient to define "investment discretion" to include all trust accounts over which a bank would hold "significant" investment discretion and thereby include all relevant advisory situations.

122. The disclosure form could be patterned after the quarterly report, Form N-1Q, submitted to the SEC by mutual funds. 3 CCH FED. SEC. L. REP. If 52,101-104, at 39,971. 978 (1971). Rule-making authority in the SEC could be used to relate "significance" to the size of the reporting trust. For example, the trust would report each purchase, salc, or holding which represents more than one percent of the trust corpus or cxcceds $\$ 500,000$, whichever is less.

123. The Morgan Guaranty Report and the Citibank 1971 Report both disclose ag. gregate holdings for the entire trust department segregated by dollar levels of portfolio investment in terms of market value. TRUST AND INVESTMENT Division, REPORT OF THE Trust and Investaient Division Morgan Guaranty Trust Company 16.28 (1972); Citr. BANK 1971 REPORT, supra note 30 , at 28 . Unless such aggregate disclosure discriminates between degrees of investment discretion given to a bank, its usefulness for analysis is quite limited.

124. The disclosure form could be patterned after the annual report, Form $N \cdot 1 R$, submitted by mutual funds to the SEC. 3 CCH FED. SEC. L. REP. $751,961-85$, at $39,891-928$ (1971). Since some banks will also be reporting quarterly, the same thirty-day laig on reporting ought to be applied to annual disclosure. Any other arrangement would lcad to unnecessary competitive advantages and disadvantages between banks.

125. SEG rule-making could expand the disclosure of bank trust department investment management policies based on public policy needs. Other items for disclosure might include: brokerage allocation policies; securities and research information allo. cation policies; conflict of interest restrictions; portfolio investment policies; and com. pensation calculations, including any performance fees earned. For cxample, while mutual fund advisors who have performance fees presently must compute symmctricil performance fees against a broadly-based index of securities, banks can bargain, meta. phorically speaking, for whatever fee the traffic will bear. 15 U.S.C. $\$ 80 \mathrm{~b} \cdot 5$ (1971). Sec also Factors to be Considered in Connection with Investment Company Advisory Con. tracts Concerning Incentive Fee Arrangements, SEC Investment Advisers Act Release No. 315 (April 6, 1972), [1971-1972 Transfer Binder] CCH FED. SEC. L. REP. I 78,694, at 
Under the above scheme, bank regulatory agencies would retain sole responsibility for bank solvency, and the SEC would collect informa. tion about investment activities. The proposed disclosure system would not be onerous; ${ }^{126}$ for it would parallel internal reports presently prepared by bank trust departments. Furthermore, the exclusion of some trust accounts from reporting and disclosure requirements would apply the burden only to those with sufficient size and/or discretion to produce potential for abuse.

\section{Conclusion}

The proposed regulatory reforms outlined in Parts II and III obviate the need for legislatively imposed constraints on bank trust department investment activities-constraints which would petrify one day's perceptions of a fast-changing field.127 An alternative to these reforms would be separate incorporation of the trust department outside the bank complex. ${ }^{128}$ Advocates of separate incorporation have argued that its implementation would reduce the potential conflicts of interest which exist within bank complexes and would reduce the disproportionate concentration of trust and commercial assets in the largest banks. ${ }^{129}$ However, few of the 3,000 new trust companies which would result from separate incorporation could survive at the present level of trust commission fees. ${ }^{130}$ Trust companies spun off from small banks,

81,462 (1972); Survey of Investment Company Incentive Fee Arrangements, SEC Investment Company Act Release No. 7130 (April 17, 1972), [1971-1972 Transier Binder] CCH FED. SEC. L. REP. T 78,700 at 81,480 (1972).

126. On January 5,1973 , the SEC released the report of its Advisory Committce on Investment Companies and Advisers. SEC Urged to Simplify Reporting for Advisers, Investment Concerns, Wall St. J., Jan. 5, 1973, at 8, col. 3. That report on the papervork filed by investment advisers and investment companies recommended: (1) establishing an integrated investment company filing system; (2) simplifying investment companj; prospectuses; (3) eliminating quarterly reporting of portfolio transactions of investment companies; and (4) requiring annual reporting with quarterly up-dating for investment

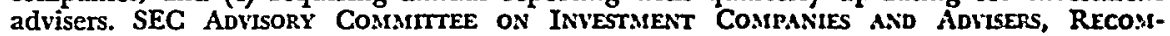
MENDATIONS FOR IMPROVEMENT OF REPORTING REQUIREMIENTS AND RELATED AREAS FOR INVESTMENT COMPANIES AND INVESTMENT ADVISERS vii-xi (Dec. 29, 1972), [1971-1972 Trans. fer Binder] CCH FED. SEC. L. REP. I 79,159, at 82,524 (1973).

127. See Hearings on H.R. 5700, supra note 98, pts. I and 2.

128. See, e.g., J. ReMington, TRust Business in the Future: Its Assochition wmi BANkinc 17 (1938). For a discussion of problems which separate incorporation might create, see Griswold, Divorcement of Trust Functions from Commercial Banl, 63 Trust Companies 293 (1936).

129. The 100 largest commercial banks, measured in terms of deposits, hold just less than fifty percent of all commercial bank deposits in the country; the 100 largest bank: trust departments hold over eighty-two percent of all bank assets. Patassi Reront, supra note 2 , at 2.

130. Some trust commission fees could be raised unilaterally. Others, such as the fees from personal estates, are usually fixed by state law. Even if trust commission fees could be raised across the whole spectrum of trust accounts, a very large increase would seriously impair banks' continuing ability to provide reasonably priced services to small accounts. But see Fowler, Investment Clubs: Leterage for the Litlle Guy, N.Y. Times, 
which presently exercise their trust powers simply to provide a needed service in their local community, would be especially hard hit. ${ }^{131}$ Finally, one potential abuse of separate incorporation-"sweetheart" reciprocal demand deposit arrangements between old bank complexes and new trust companies-would have side-effects more pernicious than either fixed minimum commission rates or any present bank reciprocal practice. ${ }^{132}$

Nonetheless, the alternative to incorporation envisioned in this Article-increased reliance on trust examiners-will succeed only if these individuals receive better training from the bank regulatory agencies in trust law, securities regulation, and modern investment practices. A commercial bank examiner who is assigned occasionally to do a trust examination simply will not be sensitive enough to the nuances of trust department investment practices. To encourage specialization in trust examination work, bank regulatory agencies must provide additional incentives, in the form of increased pay at the very least. This means higher congressional appropriations and increased spending by bank regulatory agencies.

Many of the proposals of this Article assume the willingness of bank trust departments and bank regulatory agencies themselves to formulate sound, reasonable policies. However, the constant threat of litigation and the possibility of inhibiting legislation should provide sufficient impetus for banks and bank regulatory agencies to adopt needed reforms.

Oct. 31, 1971, § 3 (Finance) at 2; Hammer, Advisory Services for Small Investor Grow, N.Y. Times, April 9, 1972, \& 3 (Finance) at 2. Yet the SEC is presently considering al. lowing the mass merchandising of investment and management services for small in. vestors. SEC Advisory CoMm. ON INVESTMENT MANAgEMENT SERvices For INdividunL INvestors REPORT, [Current] CGH FED. SEc. L. Rel. ๆ 79,193, at 82,620 (1973).

Trust commissions presently charged by existing trust companics were quite similar to those charged by banks according to interviewed trust company officials. Trust companies, however, because they are not "banks" for local law purposes, have been allowed under state law to invest their capital base in growth stocks. This extra revenue source for improving the net return on capital for trust companies reportedly exceds the credit on demand deposits received by some bank trust departments. An altcrnative to increasing the commission fees of new trust companies would be to spin off a larger share of the bank's complex capital base. This base could be invested in the way trust companies do now, possibly compensating for the loss of demand deposits revenuc.

131. Banks which are outside major money centers, and which therefore have smaller capital bases, would not be capable of spinning off sufficient assets to allow new trust companies to survive. Estate planning in many sections of the United States places great importance on the availability of a corporate trustee whose services would be lost if such trust companies failed.

132. If the new trust company merely deposited the uninvestable cash as a demand deposit with the old bank, the old bank would be forced to reward the trust company for the deposit with a panoply of "free" computer or research services since it could not pay interest on or give internal credit for the demand deposit. Even if new trust com. panies were prohibited from depositing cash with the old bank complexes, conceivably a complicated system of cross-deposits and cross-services might develop among the niation's banks. 


\section{The Yale Law Journal}

Volume 82, Number 5, April 1973

\section{RICHARD BLUMIENTHAL Editor-in-Chief}

Gurt Hessler

ROBERT B. REICH

Charles L. WoltmanN

Article Editors
ROger W. FonsecA Charles A. Golddrark Henry B. Hansmann DANIEL J. KORNSTEIN Jay E. Powell

Note \& Comment Editors

Garl E. ANDuri, Jr. RALPH R. ARDITI Alan E. Boles, JR. JOHN R. BOLTON Michael J. Bean Coleman H. Casey Michael J. Churgin Michael M. Conway Christopher C. Curtis KathleEN M. DoggetT Peter H. Ehrenberg Robert W. Fisher DONALD J. FriEDMIAN JAMES N. GARDNER NANCY G. GarRISON Robert T. GILlERAN FREDERICK GoLDBERG, JR. JOI JoHN S. GrahaM III Steven R. Gross
Peter T. Grossi, Jr. Executive Editor

Business Secretaries M. Oltve Butterfield, Pamela WirlirotT

\section{Student Contributors to This Issue}

Donald E. Scott, Takings and the Public Interest in Railroad Reorganization

Richard G. Linquanti, Quasi in Rem Jurisdiction and Due Process Requirements

Kathleen M. Doggett and Donald J. Friedman, Legislation for Clean Air: An Indoor Front

Coleman H. Casey and Stewart G. Rosenblum, A First Amendment Right of Access to the Courts for Indigents

James T. Malysiak, Toward A Substantive Privale Inlernational Law of Trademarks: The Lessons of the Carl Zeiss Litigation 